L. Valevskaya, PhD of Technical Science, Associate Professor, E-mail: ludmila_valev@ukr.net https://orcid.org/0000-0003-0511-5643, ResearcherID: F-8756-2016

O. Sokolovskaya, PhD of Technical Science, Senior Lecturer, E-mail: sokolovskaya_alena@meta.ua https://orcid.org/0000-0003-4326-1932, ResearcherID: N-5304-2015

Odessa National Academy of Food Technologies, 112, Kanatna Str., Odessa, 65039, Ukraine

\title{
DETERMINATION OF PHYSICAL AND TECHNOLOGICAL PROPERTIES OF QUINO GRAIN - THE MAIN STAGES OF JUSTIFICATION OF STORAGE AND PROCESSING TECHNOLOGY
}

\begin{abstract} standards, or used in research and recommended in the relevant literature. mass flowability.

\section{Introduction}

In recent decades, the quinoa market has grown rapidly due to its extremely beneficial properties for the body, among consumers and supporters of healthy eating. The expansion of the range of products with high nutritional value is becoming more popular due to the deficiency in the diet of people of vitamins, minerals and polyunsaturated fatty acids. The increase of food can be carried out by introducing into the recipe non-traditional types of raw materials of plant origin, containing a significant amount of macro- and micronutrients. One of the promising and new types of non-traditional vegetable raw materials for the confectionery industry is quinoa.

Quinoa is used to increase the biological value and expand the range of health products in the production of breakfast cereals, confectionery, dairy sausages, as well as a food ingredient in the production of protein bars, beverages and sports nutrition. And today, even on supermarket shelves you can find products of mass consumption with the addition of quinoa seeds, and NASA uses quinoa to create food for astronauts.
\end{abstract}

The work is devoted to determining the physical and technological properties of quinoa grain. Quinoa is an unconventional crop for Ukraine, but experiments on its cultivation have been successfully completed in the Sumy region. Due to its unique chemical composition, quinoa is used in dietary and functional products.

Quinoa contains about $20 \%$ protein, which makes it an excellent dietary supplement for people who do not eat animal products. The amino acid composition of quinoa proteins is very balanced and is characterized by a high content of such essential amino acids. Feature of the fatty acid composition of quinoa. it has a high content of polyunsaturated fatty acids, including linolenic fatty acid and linoleic, which belongs to the acids $\omega-3$ and $\omega-6$ fatty acids.

Due to the growing popularity of quinoa and its suitability for cultivation in our climatic and soil conditions, it is important to develop the technology of its storage and processing. One of the main stages of substantiation of the choice of technology for storage and processing of quinoa grain is to determine its physical and technological properties.

Physical and technological properties of grain mass are determined by a large number of indicators.

Determination of physical and technological properties of quinoa grain was performed for three types of quinoa: red, black and white. In determining the physical and mechanical properties were used methods approved by the relevant

We have identified the following basic physical and technological properties: geometric characteristics, nature, weight of 1000 grains, duty cycle, packing density, air supply, angle of natural slope, coefficient of internal friction, coefficient of external friction. Numerical values of these indicators for each type of quinoa are determined.

Knowledge of the physical and technological properties of the grain mass to solve a large number of applied problems that have practical significance. and play an important role in the processes of moistening, heating and cooling of grain. A thorough study of physical and technological properties can provide optimal conditions for storage of seeds without compromising their quality. The obtained data can be used for selection of modes of cleaning, drying and active ventilation.

Key words: quinoa, physical and technological properties, geometric characteristics, grain mass porosity, grain

This culture has a high nutritional value, protein content up to $16 \%$, about $6 \%$ lipids, more than $60 \%$ carbohydrates. The amino acid composition of quinoa proteins is characterized by a high content of such essential amino acids as valine, leucine, isoleucine, lysine, threonine and phenylalanine. Quinoa is considered an alternative oil crop because of the quality and quantity of its lipid fraction, as its grains are rich in essential fatty acids such as linoleic and $\alpha$-linolenic, and contain high concentrations of natural antioxidants such as $\alpha$ - and $\gamma$ tocopherol. Quinoa is rich in trace elements such as vitamins and minerals. Among the vitamins in large quantities in quinoa are B vitamins - thiamine B1, riboflavin B2, folic acid B9, as well as niacin PP, vitamins A (retinol) and vitamin $E$ (tocopherol). The mineral content is $2.3 \%$, including more than $500 \mathrm{mg}$ of potassium, about $200 \mathrm{mg}$ of magnesium and more than $400 \mathrm{mg}$ of phosphorus, $500 \mathrm{mg}$ of copper per $100 \mathrm{~g}$ of product [1,2].

Quinoa seeds have attracted much attention around the world not only because of their nutritional and functional properties, but also because of their ability to 
be cultivated in adverse climatic conditions. Quinoa grains are resistant to frost, salinity, drought and can grow on marginal soils. Therefore, these characteristics are very relevant for areas prone to food security.

According to the Center for International Trade, the value of world exports of quinoa grains increased by more than $300 \%$ between 2013 and 2018 - from \$ 135 million to $\$ 420$ million. Most traders predict further price increases as demand exceeds supply.

Unfortunately, quinoa seeds are not grown en masse in our country yet, although there is already a successful experience. Scientists are convinced that this culture has very great prospects in our country [1].

In this regard, the question of finding optimal ways to prepare freshly harvested quinoa seeds and their storage becomes relevant.

One of the main stages of substantiation of the choice of technology for storage and processing of quinoa grain is to determine its physical and technological properties.

Grain mass has certain physical properties flowability, self-sorting, porosity, ability to sorption and desorption of various vapors and gases (sorption capacity), heat, temperature and thermal conductivity, heat capacity. Knowledge and consideration of the physical properties of grain masses are of particular importance in connection with mechanization and automation of grain processing and storage, introduction of new drying methods, use of pneumatic transport and storage of large batches in large storages (silos of modern elevators, metal bunkers, warehouses). ). Knowledge of the physical and technological properties of grain mass as a bulk material allows to solve a large number of applied problems that have practical significance. Skillful use of these properties allows to reduce losses, to improve quality of batches of grain and to reduce expenses in all branches of a national economy connected with production and use of grain.

Physical and technological properties of grain mass are determined by a significant number of indicators, the choice of which depends on the tasks. For the grain mass the main technological value is its biometric characteristics, size and evenness of the grain mass [3].

Only a thorough study of physical and technological properties can provide optimal conditions for grain storage without compromising its quality.

The aim of the work is the technological evaluation of quinoa seeds, ie the study of physical and technological properties of quinoa seeds.

Object of research: physical and technological properties of quinoa grain.

Subject of research: three types of quinoa seeds: red, black and white.

\section{Research methodology}

In determining the physical and mechanical properties were used methods approved by the relevant DSTU, or used in research and recommended in the relevant literature.

Grain moisture was determined according to GOST 13586.5-93, the mass of 1000 grains according to DSTU ISO 520: 2015, the angle of natural slope according to GOST 28254-89 and the bulk density (nature) ac- cording to DSTU GOST 10840: 2019.

The method of research of geometric dimensions was to determine the length 1 , width a and thickness $\mathrm{b}$ of quinoa seeds and further processing of measurement results by methods of variation statistics. The measurements were performed with a caliper with an accuracy of $0.1 \mathrm{~mm}$. During mathematical processing, the array of experimental data was checked for possible errors, divided into classes and frequencies, and then determined the average size of the studied seeds (length $l$, width $a$, thickness $b$ ) and a number of statistical characteristics variation of variation of linear sizes, classes, frequency and grain mode (values of geometric grain sizes that are observed the largest number of times). The main geometrical parameters such as grain volume $V_{z}$, outer surface area $F_{z}$, equivalent diameter $d_{e}$ and specific surface area $\mathrm{a}_{0}$ and sphericity $\psi$ of seeds were calculated $[8,9]$.

We also performed statistical evaluation of the obtained results, which is reduced to the rough errors of the experiments, calculation of the average values of observations $\bar{y}_{u}$, determination of sample variances of $S_{y}{ }^{2}$ for estimating random errors, as well as calculation of relative errors and a number of other statistical characteristics. Calculations of coefficients in the equations of mathematical models were performed according to standard programs [4].

\section{Research results}

The shape and linear dimensions of the grain determine the choice of separation schemes, the characteristics of the working bodies of the separating machines, cultivators, grain separators, as well as the working bodies of the grinding machines. Volume and outer surface play an important role in the processes of moistening, heating and cooling of grain [3, 5-7].

The geometric characteristics of the grain determine the density of stacking during the formation of the layer (porosity) and especially during movement or transportation. The complexity of the structure of technological processes is characterized by a significant length of ways of processing grain products, which can reach several kilometers in machines and various transport mechanisms (pneumatic pipes, norias, conveyors, etc.) $[3,5]$.

To characterize the geometric features of the grain is not enough to specify only the linear dimensions. The average values of the linear grain sizes studied were used to determine the values of volume, area and sphericity, which play an important role in the processes of moistening, heating and cooling of grain. Changes in size affect the grain volume, outer surface area, sphericity and $V / F$ ratio, which characterize the alignment in size, which affects the conduct of the technological process $[9,10]$.

Geometric characteristics are important for heat and water transfer processes, especially during hydrothermal treatment of grain. All indicators of the geometric characteristics of the grain change significantly. Due to this, the values of volume, area of the outer surface of the grain, their ratio and sphericity vary.

Particle size distribution is a characteristic that determines the geometric dimensions of grains and the ratio of their sizes in the total grain mass. A number of important geometrical characteristics were also deter-

 
mined for each grain sample (Table 1). The main geometric parameters such as grain volume $V_{z}$, outer surface area $F_{z}$, equivalent diameter $d_{e}$ and specific surface area $\mathrm{a}_{0}$ and sphericity $\psi$ of seeds were calculated $[9,10]$.

It is determined that the largest geometric dimensions are red quinoa seeds - length $2.0 \mathrm{~mm}$, width 1.8 $\mathrm{mm}$ and thickness $1.10 \mathrm{~mm}$, white quinoa seeds are characterized by the following sizes $-1.8 \mathrm{~mm}, 1.7 \mathrm{~mm}$ and $1.10 \mathrm{~mm}$ and black quinoa seeds have the smallest dimensions of $1.7 \mathrm{~mm}, 1.6 \mathrm{~mm}$ and $1.0 \mathrm{~mm}$, respectively, length, width and thickness. In the table. 1 shows the calculated values of the geometric characteristics of different types of quinoa.

If we compare quinoa seeds with other crops, they are similar in size to rapeseed, so no special sowing or technological equipment is required $[9,10]$.

At the next stage of our work, the physical and technological properties of quinoa grain of three types were determined. The results are given in table. 2 .

The grain mass when placed in warehouses or silos does not form a dense mass, between its solid components there are free gaps filled with air. The density of grain stacking and the duty cycle of the grain mass are expressed as a percentage of the total grain mass. The stacking density and the duty cycle of the grain mass are of great practical importance during storage. The presence of air in the intergranular space affects the change in temperature and humidity of the grain mass and determines the influence of physiological processes that take place in it [12].
The sparseness of the grain mass is of great importance for maintaining the viability of seeds, which is very important when storing seed lots. The packing density and porosity of the grain mass in storage depends on the shape, elasticity, size and condition of the surface of solid components of the grain mass, the number and type of impurities in it, the batch size and moisture content of grain mass, shape and size of storage, method of filling, and shelf life. Therefore, the values of stacking density and duty cycle of the grain mass can vary considerably. [12].

These studies show that indicators such as laying density and porosity for different types of quinoa seeds do not differ significantly and are in the range of $38.0 \ldots 41.6 \%$ in porosity and $58.4 \ldots 62.0 \%$ in packing density.

One of the important characteristics of the grain mass is the supply of air to the grain mass or the volume of air in 1 ton of grain mass. Multiplying the volume of air in 1 ton of grain mass by the total weight of the batch of grain, determine the amount of one air exchange. This indicator is used for active ventilation of grain masses and for different types of quinoa seeds it is $0.64 \ldots 0.69$ $\mathrm{m}^{3} / \mathrm{t}$.

The flowability of the grain mass is characterized by the coefficients of external and internal friction, which are determined by measuring the angles of friction and natural slope. The studied samples of quinoa seeds can be attributed to well-flowing products, because the angle of natural slope in it is less than 35 degrees, which must be taken into account in the technology of its postharvest processing.

Table 1 - Geometric characteristics of quinoa grain

\begin{tabular}{|c|c|c|c|c|c|}
\hline $\begin{array}{l}\text { Type of } \\
\text { quinoa }\end{array}$ & $\begin{array}{l}\text { Grain volume } \\
\text { Vz mm }\end{array}$ & $\begin{array}{l}\text { Outer surface } \\
\text { area } \mathrm{Fz}, \mathrm{mm}^{2}\end{array}$ & $\begin{array}{c}\text { Equivalent } \\
\text { diameter } d_{e}, \mathrm{~mm}\end{array}$ & $\begin{array}{l}\text { Specific surface } \\
a_{0},\left(\mathrm{~mm}^{2} / \mathrm{mm}^{3}\right)\end{array}$ & $\begin{array}{c}\text { Sphericity, } \\
\psi\end{array}$ \\
\hline Red & 2,65 & 8,27 & 1,72 & 3,12 & 0,89 \\
\hline "White & 2,23 & 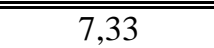 & "1,62 & 3,28 & "0,89 \\
\hline Black & $\bar{~} 1,82$ & 6,40 & $\overline{11,52}$ & 3,51 & "0,89 \\
\hline
\end{tabular}

Table 2 - Physical and technological properties of quinoa grain

\begin{tabular}{|c|c|c|c|}
\hline The name of the indicator & Red & White & Black \\
\hline Mass fraction of moisture, $\%$ & 9,6 & 10,0 & 9,8 \\
\hline Nature (volume mass), $\mathrm{kg} / \mathrm{m}^{3}$ & 595 & 580 & 588 \\
\hline Mass 1000 grains, $\mathrm{g}$ & 3,36 & 3,48 & 3,42 \\
\hline True volume of 1000 grains, $\mathrm{cm}^{3}$ & 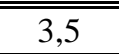 & 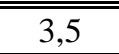 & 3 \\
\hline Toughness, $\%$ & 38,0 & 41,6 & 39,8 \\
\hline Laying density, \% & 62,0 & 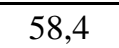 & 60,2 \\
\hline Air supply, $\mathrm{m}^{3} / \mathrm{t}$ & 0,64 & 0,69 & 0,68 \\
\hline The angle of the natural slope & 31 & 32 & 31 \\
\hline \multicolumn{4}{|l|}{ Coefficients of external friction at rest: } \\
\hline on plastic & 0,2424 & 0,2654 & 0,2856 \\
\hline on steel & 0,2489 & 0,2752 & 0,3010 \\
\hline on rubber & 0,2554 & 0,2760 & 0,3125 \\
\hline Coefficient of external friction in motion & 0,4282 & 0,4068 & 0,4154 \\
\hline
\end{tabular}


Conclusions

Quinoa seeds are in great demand among consumers, but have not yet shown great popularity among producers. The plant adapts well to our climatic and soil conditions. Suitability for cultivation in Ukraine in the near future, given the development trends of the consumer market, can ensure the growth of production.

The basic geometrical indicators of grain which allow to model processes of ventilation, drying, to select mode parameters of technological cars are calculated.
Physical and technological properties of different types of quinoa grains, weight of 1000 grains, nature, porosity, density of laying, angle of natural slope, coefficient of internal friction and coefficient of external friction are investigated.

The presented research results will allow to substantiate the rational regimes of technological processes of post-harvest processing and to become the first step to the development of quinoa grain storage technology.

\section{REFERENCES}

1. Valevs'ka L.O., Sokolovs'ka O.H., Shulyans'ka A.O Biolohichna tsinnist' zernovykh superfudiv // Vcheni zapysky TNU imeni V.I. Vernads'koho. Seriya: tekhnichni nauky Tom 31 (70) № 12020 CH.2. 116-120.

2. FAO \& CIRAD. 2015. State of the Art Report of Quinoa in the World in 2013, by D. Bazile, D. Bertero \& C. Nieto, eds. Rome.

3. Osokina. N.M. Kostets'ka K.V. Tekhnolohichna otsinka zerna pshenytsi ta trytykale dlya krup'yanoho vyrobnytstva // Visnyk Umans'koho natsional'noho universytetu sadivnytstva №2, 2015. 28-33.

4. Ostapchuk M.V., Stankevych H.M. Matematychnemodelyuvannya na EOM: pidruch. Odesa: Druk, 2006. 313.

5. Puzik L. M., Puzik V. K. Tekhnolohiya zberihannya i pererobky zerna: navchal'nyy posibnyk. Kharkiv: TOCHKA, 2013. 312

6. Sokolova A.YA. Tekhnolohycheskoe oborudovanye predpryyatyy po khranenyyu y pererabotke zerna. Moskva: Kolos, 1984. 445.

7. Zverev S.V. Fyzycheskye svoystva zerna y produktov eho pererabotky. Moskva: DeLyprynt, 2007. 176.

8. Zhemela H.P., Barabolya O.V. Tekhnolohiya boroshnomel'noho ta krup"yanoho vyrobnytstva: navchal'nyy posibnyk dlya studentiv. Poltava. 2011. 292.

9. Stankevych, H.M., Ovsyannykova L.K., Sokolovs'ka O.H. Obrobka ta zberihannya dribnonasinnyevykh oliynykh kul'tur: monohrafiya. Odesa: KP OMD, 2016. 128

10. Ovsyannykova, L.K., Orlova S.S., Sokolovs'ka O.H. Porivnyal'nyy analiz dribnonasinnyevykh kul'tur na osnovi statystychnykh kharakterystyk yikh rozmiriv/l Nauk. pr. / Odes. nats. akad. kharch. tekhnolohiy. Odesa, 2009. Vyp. 36, t. 1. 72-76.

11. Starodubtseva A.Y, Serhunov V.S. Praktykum po khranenyyu zerna. Moskva: Ahropromyzdat, 1987. 191.

12. Vanshyn V.V. Praktykum po khranenyyu zerna. Orenburh: HOU OHU. 2009. 47

Л.О. Валевська, канд. техн. наук, доцент, E-mail: ludmila_valev@ukr.net https://orcid.org/0000-0003-0511-5643, ResearcherID: F-8756-2016

О.Г. Соколовська, канд. техн. наук, ст. викл., E-mail: sokolovskaya_alena@meta.ua https://orcid.org/0000-0003-4326-1932, ResearcherID: N-5304-2015

Кафедра технології зберігання зерна Одеська національна академія харчових технологій, вул. Канатна, 112, Одеса, 65039, Украӥна

\section{ВИЗНАЧЕННЯ ФІЗИКО-ТЕХНОЛОГІЧНИХ ВЛАСТИВОСТЕЙ ЗЕРЕН КІНОА - ОСНОВНИЙ 3 ЕТАПІВ ОБГРУНТУВАННЯ ТЕХНОЛОГІЇ ЗБЕРІГАННЯ ТА ОБРОБКИ}

\section{Анотація}

Робота присвячена визначенню фізико-технологічних властивостей зерна кіноа. Кіноа є нетрадиційною для Украӥни агрокультурою, проте експерименти по ї̈ вирощуванню успішно завершилися в Сумській області. Завдяки своєму унікальному хімічному складу кіноа використовується у продуктах дієтичного та функиіонального призначення.

Кіноа містить близько 20\% білків, щзо робить ї̈ чудовим харчовою добавкою для людей, які не вживають продуктів тваринного походження. Амінокислотний склад білків кіноа дуже збалансований $і$ характеризується високим вмістом незамінних амінокислот. Особливістю жирнокислотного складу зерен кіноа є високий вміст у ньому поліненасичених жирних кислот, у тому числі ліноленової жирної кислоти та лінолевої, щзо відноситься до кислот $\omega-3$ та $\omega-6$ жирних кислот.

У зв'язку із ростом популярності кіноа та ї̈ придатності до вирощування у наших природнокліматичних і грунтових умовах с актуальним розробка технологї̈ ї̈ зберігання та обробки. Одним з основних етапів обгрунтування вибору технологї зберігання та обробки зерен кіноа є визначення його фізикотехнологічних властивостей. 
Фізико-технологічні властивості зернової маси визначаються значною кількістю показників.

Визначення фізико-технологічних властивостей зерна кіноа проводили для трьох видів кіноа: червоне, чорне та біле. При визначенні фізико-механічних властивостей були використані методи, затверджені відповідними стандартами, або, щэо застосовані в науково-дослідних роботах і рекомендовані у відповідній літераmypi.

Нами було визначено такі основні фізико-технологічні властивості: геометричні характеристики, натура, маса 1000 зерен, шпаруватість, щільність укладання, забезпеченість повітрям, кут природного укосу, коефічієнт внутрішнього тертя, коефіцієнта зовнішнього тертя. Визначено числові значення изих показників для кожного виду кіноа.

Знання фізико-технологічних властивостей зернової маси дозволяє вирішувати велику кількість прикладних задач, які мають практичне значення і відіграють важливу роль у процесах зволоження, нагріву й охолоджування зерна. Досконале вивчення фізичних і технологічних властивостей може забезпечити оптимальні умови для зберігання насіння без погіршення його якості. Отримані дані можна використовувати для підбору режимів очищення, сушіння й активного вентилювання.

Ключові слова: кіноа, фізико-технологічні властивості, геометричні характеристики, ипаруватість зернової маси, сипкість зернової маси.

\section{ЛІТЕРАТУРА}

1. Валевська Л.О., Соколовська О.Г., Шулянська А.О Біологічна иінність зернових суперфудів // Вчені записки ТНУ імені B.I. Вернадського. Серія: технічні науки Том 31 (70) № 12020 Ч.2. C.116-120

2. FAO \& CIRAD. 2015. State of the Art Report of Quinoa in the World in 2013, by D. Bazile, D. Bertero \& $C$. Nieto, eds. Rome.

3. Осокіна. Н.М. Костецьька К.В. Технологічна оцінка зерна пшениці та тритикале для круп'яного виробництвв // Вісник Уманського національного університету садівництва №2, 2015 C.28-33.

4. Остапчук М.В., Станкевич Г.М. Математичнемоделювання на ЕОМ: підруч. Одеса: Друк, 2006.313 с.

5. Пузік Л. М., Пузік В. К. Технологія зберігання і переробки зерна: навчальний посібник. Харків: ТОЧКА, 2013. $312 \mathrm{c}$.

6. Соколова А.Я. Технологическое оборудование предприятий по хранению и переработке зерна. Москва: Колос, 1984. 445 c.

7. Зверев С.В. Физические свойства зерна и продуктов его переработки. Москва: ДеЛипринт, 2007. 176 с.

8. Жемела Г.П., Бараболя О.В. Технологія борошномельного та круп'яного виробництва: навчальний посібник для студентів. Полтава. 2011. 292 с

9. Станкевич, Г.М., Овсянникова Л.К., Соколовська О.Г. Обробка та зберігання дрібнонасіннєвих олійних культур: монографія. Одеса: КП ОМД, 2016. 128 с.

10. Овсянникова, Л.К., Орлова С.С., Соколовська О.Г. Порівняльний аналіз дрібнонасіннєвих культур на основі статистичних характеристик їх розмірів// Наук. праці Одес. нац. акад. харч. технологій. Одеca, 2009. Bun. 36, m. 1. C. 72-76.

11. Стародубиева А.И, Сергунов В.С. Практикум по хранению зерна. Москва: Агропромиздат, 1987. 191.

12. Ваншин В.В. Практикум по хранению зерна. Оренбург: ГОУ ОГУ. 2009.47 с.

\section{Received 18.01.2021 \\ Reviewed 02.02.2021}

\section{Revised 22.02.2021 Approved 30.03.2021}

\section{Cite as Vancouver Citation Style}

Valevskaya L., Sokolovskaya O. Determination of physical and technological properties of quino grain -the main stages of justification of storage and processing technology. Grain products and mixed fodder's, 2021;21 (1, 81): 4-8. DOI https://doi.org/

\section{Cite as State Standard of Ukraine 8302:2015}

Determination of physical and technological properties of quino grain -the main stages of justification of storage and processing technology. / Valevskaya L. et al. // Grain Products and Mixed Fodder's. 2021. Vol. 21, Issue 1 (81). P. 48. DOI https://doi.org/ 